\title{
Visual and Auditory Sustained Attention in Children with Speech Sound Disorders with and without Comorbid Language Disorders
}

\author{
Mi-Jin Joo ${ }^{\mathrm{a}, \mathrm{b}}$, Ji-Wan $\mathrm{Ha}^{\mathrm{a}, \mathrm{c}}$ \\ a'Department of Speech \& Language Pathology, Graduate School of Rehabilitation Science, Daegu University, Gyeongsan, Korea \\ ${ }^{b}$ Jamo Speech Language Psychology Development Center, Busan, Korea \\ 'Department of Speech Pathology, Daegu University, Gyeongsan, Korea
}

Correspondence: Ji-Wan $\mathrm{Ha}, \mathrm{PhD}$ Department of Speech Pathology, Daegu University, 201 Daegudae-ro, Jillyang-eup, Gyeongsan 38453, Korea

Tel: $+82-53-850-4327$

Fax: +82-53-850-4329

E-mail: jw-ha@daegu.ac.kr

Received: April 6, 2018

Revised: May 12, 2018

Accepted: May 19, 2018

This work was supported by the Daegu University Research Grant 2015 (No. 20150400).

\begin{abstract}
Objectives: Although research has demonstrated that children with specific language impairment and reading disorders exhibit sustained attention deficits, there have been few studies about sustained attention in children with speech sound disorders. This study investigated the performance of children with pure speech sound disorders (pure SSD), children with speech sound disorders and comorbid language disorders (SSD+LD), and typically developing (TD) peers on visual and auditory sustained attention tasks. Methods: Both visual and auditory tasks were used to assess sustained attention in 20 6-year-old children with SSD (10 pure SSD, 10 SSD+LD) and 20 TD age-matched controls. The accuracy score and response time were analyzed, and the correlation among receptive and expressive vocabulary sizes, accuracy of articulation, and performance of tasks was examined. Results: The pure SSD group and SSD+LD group performed significantly worse on both visual and auditory tasks than the TD group. The response time of the SSD+LD group was significantly slower on both tasks than the TD group. The response time of the auditory task was significantly slower than that of the visual task in all groups. In the SSD group, the correlation between the accuracy of articulation and visual/auditory sustained attention, and the correlation between expressive vocabulary size and auditory sustained attention were significantly positive. Conclusion: Children with SSD with and without LD have reduced attention skills that could contribute to speech sound learning. These results suggest that attention difficulties could be one of the underlying factors of the speech sound impairment in children with SSD.
\end{abstract}

Keywords: Pure speech sound disorder, Speech sound disorder with comorbid language disorder, Visual sustained attention, Auditory sustained attention
말소리장애는 아동기에 발생하는 가장 빈번한 의사소통장애로 (Murphy, Pagan-Neves, Wertzner, \& Schochat, 2014), 이와 관련한 주요 요인으로 말지각, 음운인식, 음운처리, 음운단기기억, 음운작 업기억 등의 결함이 언급되고 있다(Bird \& Bishop, 1992; Kenney, Barac-Cikoja, Finnegan, Jeffries, \& Ludlow, 2006; Leitao \& Fletcher, 2004; Seo, Ko, Oh, \& Kim, 2017). 이는 모두 말소리 정보에 대한 처리 능력을 요구하는 활동이기 때문에, 성공적인 정보처리를 위
해서는 기본적으로 주의력이 요구된다. 주의력은 언어학습을 위해 필수적으로 갖춰야 할 요인일 뿐 아니라(Campbell \& McNeil, 1985), 모든 의도된 행동에 기초적인 처리과정이다(Brookshire, 2007). 때 문에 정상적인 주의력은 말소리 학습을 위해서도 반드시 선행되어 야 할 조건이다. 말소리 습득이 정상적으로 이루어지지 않은 말소 리장애 아동에서 주의력이 충분히 발달되지 않았을 가능성, 그리 고 말소리 결함과 관련 있는 지각, 인식, 기억 등이 주의력과 밀접한 
연관이 있다는 사실 등에 근거할 때, 말소리장애 아동의 주의 특성 에 대해 살펴볼 필요가 있으나 이에 대한 연구는 많지 않다.

그러나 언어장애 아동과 읽기장애 아동의 주의력 저하 또는 주 의력결핍 과잉행동장애(ADHD)의 동반 가능성(Finneran, Francis, \& Leonard, 2009; Rucklidge \& Tannock, 2002; Spaulding, Plante, \& Vance, 2008; Willcutt \& Pennington, 2000), 그리고 두 장애 와 말소리장애의 높은 동반가능성(McGrath et al., 2008) 등을 종 합적으로 고려할 때, 말소리장애 아동 또한 언어장애나 읽기장애 아동처럼 주의력이 취약할 가능성을 유추해볼 수 있다. 말소리장 애, 언어장애, 읽기장애 사이에 직접적 관련성을 밝히는 것은 쉽지 않으나, 이 세 장애가 음운처리의 결함을 공유하고 더 나아가 복잡 한 음운처리 또는 음운작업기억 수행의 근간을 이루는 주의력 결 함이 그 기저에 있을 가능성을 제안한 연구들을 찾아볼 수 있다 (McGrath et al., 2008; Murphy et al., 2014).

연구자마다 다양한 방식으로 주의력에 대해 정의하고 있지만, 가 장 보편적으로 받아들여지는 주의에 관한 설명은 제한된 용량 체 계(limited-capacity system) 가설이다. 제한된 용량 체계 가설은 Broadbent (1958)가 처음 제안한 것으로, 모든 인지처리를 위해서 는 주의가 요구되는데 인지처리에 사용할 수 있는 인간의 주의 자 원의 양은 한정적이라는 것이다. 따라서 과제 수행 시 요구(demand) 가 증가하면 주의에 대한 요구도 증가하고, 그 결과 남아있는 주의 자원의 양은 감소하게 된다. 이와 같은 이유로 동시에 여러 과제를 수행하게 되면 한 과제에 필요한 주의 양으로 인해 다른 과제에 사 용할 수 있는 주의 양은 줄어들고, 결국 다른 과제를 성공적으로 수 행할 가능성이 줄어드는 교환효과(trade-off)가 발생한다. 이러한 가설에 근거하여 언어장애 아동의 주의력 결함이 또래 일반 아동 들과 비교하여 주의 자원 용량이 부족하기 때문이며, 이는 언어학 습의 문제를 야기하는 기저 요인이라고 보고되기도 하였다(Ellis Weismer, 1996; Leonard, 1998).

주의력에는 여러 유형이 있다. Sohlberg와 Mateer (2001)는 주의 처리과정을 초점주의력(focused attention), 지속주의력(sustained attention), 선택주의력(selective attention), 교대주의력(alternating attention), 그리고 분할주의력(divided attention)의 다섯 가지 유형 으로 분류하였다. 복잡한 인지처리를 위해서는 이 다섯 가지 주의 처리 능력을 모두 갖추고 있어야 하겠지만, 언어학습에는 특히 지 속주의력이 중요한 역할을 한다(Finneran et al., 2009). 지속주의력 이란 비교적 긴 시간 동안 자극에 주의를 유지할 수 있는 능력을 말 하는데, 자극이 가지고 있는 정보를 처리하기 위해서는 기본적으 로 지속주의력이 요구된다. 다시 말해 언어정보 자극을 정확하게 지각하고 해석하기 위해서는 말소리 입력 자극에 일정 시간 동안
주의를 유지할 수 있어야 하고, 그러면서 청자들은 관련 있는 정보 는 받아들이고 관련 없는 정보는 무시하게 될 것이다. 아동들이 언 어를 습득하거나 학습하기 위해서는 기본적으로 정상적인 지속적 주의력이 있어야하고, 정확한 음운체계를 습득하여 완성시켜 나가 기 위해서도 마찬가지일 것이다. 따라서 의사소통장애 아동들을 대상으로 한 연구들은 대부분 지속적 주의력에 대해 다루고 있다.

지속적 주의력은 주로 컴퓨터에 제시되는 일련의 자극 가운데 특정 목표자극이 감지될 때마다 반응하도록 하는 과제를 사용하 여 평가한다. 지속적으로 주의를 유지하는 능력을 평가하는 것이 기 때문에 자극은 길고 단조로운 간격으로 제시된다(Brookshire, 2007). 여러 자극 가운데 목표자극에만 선택적으로 주의를 기울여 야하기 때문에, 과제 특성상 선택주의력과의 경계가 모호해지기도 하여 연구자에 따라서는 지속적 선택주의력이라고 하기도 한다 (Hanson \& Montgomery, 2002). 과제의 자극은 주로 신호음, 숫자, 문자, 단어 등을 이용한다. 신호음은 청각적 자극, 문자는 시각적 자 극만 가능하지만, 숫자와 단어는 청각과 시각의 두 가지 양식(modality) 모두로 입력될 수 있다. 이러한 자극 양식과 관련하여 단순 언어장애나 말소리장애, 즉 의사소통장애 아동은 청각 양식에서 만 결함을 보인다는 연구(Noterdaeme, Amorosa, Midenberger, Sitter, \& Minow, 2001; Spaulding et al., 2008), 청각 및 시각 양식 모 두에서 수행력이 떨어진다는 연구(Finneran et al., 2009) 등, 상반 된 결과가 보고되기도 하였다. 이는 주의력이 청각과 시각 양식에 대해 분리된 용량을 가지고 있어 구어 또는 말소리 측면에 손상이 있는 의사소통장애 아동의 경우 청각 주의력에만 결함을 보이는 지, 아니면 주의력은 공통된 단일 자원(resource)으로 이루어져 있 기 때문에 주의력에 결함이 있으면 청각이든 시각이든 상관없이 어 떤 자극 양식에서도 수행력이 떨어지는지에 대한 문제로, 이에 대 해서는 연구가 더욱 진행되어야 할 것이다.

본 연구에서는 상대적으로 연구가 활발하게 이루어지지 않은 말 소리장애 아동의 주의 처리특성에 대해 다뤄 보고자 하였다. 말소 리장애는 언어장애를 동반할 가능성이 높다. 앞에서 언급하였듯 이 말소리장애와 언어장애가 모두 주의력 결함과 관련이 있다면, 말소리장애만 있는 경우와 말소리장애와 언어장애를 모두 보이는 경우를 구분하여 대상자들의 주의 특성을 살펴보는 것이 타당할 것이다. 따라서 본 연구의 대상자는 아무런 동반 장애가 없고 말소 리 산출에만 문제를 보이는 순수 말소리장애 아동(children with pure speech sound disorder, pure SSD), 언어장애를 동반한 말소리 장애 아동(children with speech sound disorder and language disorder, SSD+LD)과 일반 아동(typically developing children, TD)의 세 집단으로 구분되었다. 의사소통장애와 주의력의 관련성에 관심 
을 가졌던 선행연구들과 마찬가지로 본 연구에서도 세 집단 간 지 속주의력에 대해 비교하였다. 또한 자극 양식에 따른 주의력 차이 에 일치된 결론을 내리지 못하였던 만큼, 시각과 청각 양식에 따른 대상자들의 지속주의과제 수행력 차이도 살펴보고자 하였다. 대상 자들의 수행력은 정반응 점수와 반응시간의 두 가지 측면에서 비 교하였다. 마지막으로 지속주의과제의 수행력이 대상자들의 어휘 능력 및 말소리산출 능력과 유의한 관련성이 있는지를 알아보았다. 어휘 능력과 말소리산출 능력을 파악하기 위해, 표준화 검사의 수 용어휘량 및 표현어휘량, 그리고 자음정확도를 각각 이용하였다. 이 상과 같은 본 연구의 연구질문을 정리하면 다음과 같다.

첫째, pure SSD, SSD+LD, TD 세 집단 간 시각적 및 청각적 자극 양식에 따른 지속주의과제의 정반응 점수에 차이가 있는가?

둘째, pure $\mathrm{SSD}, \mathrm{SSD}+\mathrm{LD}, \mathrm{TD}$ 세 집단 간 시각적 및 청각적 자극 양식에 따른 지속주의과제의 반응시간에 차이가 있는가?

셋째, 대상자들의 시각적 및 청각적 지속주의과제 수행력과 수 용어휘량, 표현어휘량, 자음정확도 간 상관관계가 있는가?

\section{연구방법}

\section{연구대상}

본 연구는 6세 pure SSD 10명, SSD+LD 10명, TD 20명을 대상으 로 하였다. 생활연령을 6 세로 한정한 이유는 본 연구의 실험과제가 빠른 시간 내에 숫자 자극을 보거나 듣는 활동을 바탕으로 한 만 큼, 6 세보다 어린 아동의 경우 소리내지 않고 숫자를 빨리 읽는 것 이 능숙하지 않을 가능성이 있기 때문이었다. 대상자 선정 기준은 다음과 같다. TD 집단은 (1) 수용-표현어휘력검사(REVT; Kim, Hong, Kim, Jang, \& Lee, 2009)의 백분위 점수가 -1 SD 이상에 속 하고, (2) 우리말 조음·음운평가(U-TAP; Kim \& Shin, 2004)의 단 어 수준에서 자음정확도가 -1 SD 이상에 속하고, (3) 전문 언어재 활사에 의해 조음기관의 구조적인 장애를 지니고 있지 않은 것으로 평가되었고, (4) 부모 및 교사 보고를 통해 감각적, 신경학적, 신체 적, 인지적, 언어적 면에 아무런 문제가 없는 것으로 확인된 아동이 었다. SSD 집단은 전문 언어재활사에 의해 pure SSD 또는 $\mathrm{SSD}+\mathrm{LD}$ 로 진단받은 아동들로, 다음과 같은 기준에 근거하여 대상자들이 각각 pure SSD와 SSD+LD 집단에 속하는지 연구자들이 확인하였 다. pure SSD 집단은 (1) 수용·표현어휘력검사 결과 해당 연령의 -1 $\mathrm{SD}$ 이상의 성취를 보이고, (2) 우리말 조음·음운평가 결과 단어 수 준의 자음정확도가 $-2 \mathrm{SD}$ 이하에 속하고, (3) 전문 언어재활사에 의해 조음기관의 구조적인 장애를 지니고 있지 않은 것으로 평가되 었고, (4) 부모와 교사 보고에 의해 감각적, 신경학적, 신체적인 결함
Table 1. Participants' characteristics in pure SSD, SSD+LD, and TD groups

\begin{tabular}{lccc}
\hline & Pure SSD (N=10) & SSD+LD (N=10) & TD (N=20) \\
\hline Gender (male:female) & $5: 5$ & $7: 3$ & $9: 11$ \\
Chronological age (mo) & $77.60(3.04)$ & $76.90(2.59)$ & $76.75(3.31)$ \\
Vocabulary age (mo) & & & \\
REVT-Receptive & $79.80(4.24)$ & $55.40(4.29)$ & $74.85(4.90)$ \\
REVT-Expressive & $78.50(2.73)$ & $58.90(3.53)$ & $76.75(3.75)$ \\
U-TAP & & & \\
PCC (\%) & $87.50(4.05)$ & $85.10(4.57)$ & $99.7(.92)$ \\
\hline
\end{tabular}

Values are presented as mean (SD).

$\mathrm{SSD}=$ speech sound disorder; $\mathrm{LD}=$ language disorder; $\mathrm{TD}$ = typically developing; $\mathrm{PCC}=$ percentage of consonants correct; $\mathrm{REVT}=$ Receptive \& Expressive Vocabulary Test (Kim, Hong, Kim, Jang, \& Lee, 2009); U-TAP=Urimal Test of Articulation and Phonology (Kim \& Shin, 2004).

이 없고 인지적, 언어적 문제가 없는 아동이었다. $\mathrm{SSD}+\mathrm{LD}$ 집단은 (1) 수용·표현어휘력검사 결과 해당 연령의 $-2 \mathrm{SD}$ 이하의 성취를 보 이고, (2) 우리말 조음·음운평가 결과 단어 수준의 자음정확도가 $-2 \mathrm{SD}$ 이하에 속하고, (3) 전문 언어재활사에 의해 조음기관의 구조 적인 장애를 지니고 있지 않은 것으로 평가되었고, (4) 부모와 교사 보고에 의해 감각적, 신경학적, 신체적인 결함이 없고 인지적 문제 가 없는 아동이었다.

세 집단 간 생활연령 및 성별에는 유의한 차이가 없었다( $p>.05)$. pure $\mathrm{SSD}$ 와 SSD+LD 집단은 $\mathrm{TD}$ 집단보다 자음정확도가 유의하게 떨어졌다 $(p<.001)$. pure SSD 집단은 SSD+LD 집단보다 평균적으 로 자음정확도가 높았지만 두 집단 간 차이는 통계적으로는 유의 하지 않았다( $p>$.05). SSD+LD 집단은 pure SSD와 TD 집단보다 수 용어휘 및 표현어휘 원점수가 유의하게 떨어졌다 $(p<.001)$. 이와 같 은 세 집단의 성별, 연령, 수용 및 표현어휘 등가연령, 그리고 자음정 확도에 대한 정보는 Table 1과 같다.

\section{실험 과제}

실험자극 선정

본 연구의 실험자극은 숫자 1 부터 5 까지의 숫자로 구성되었다. 시 각적 지속주의과제는 모니터 화면에 숫자가 시각적으로 제시되고, 청각적 지속주의과제는 스피커를 통해 숫자가 청각적으로 제시된 다. 시각적 지속주의과제에서는 2 와 5 를 목표자극으로, 청각적 지 속주의과제에서는 1 과 4 를 목표자극으로 선정하여, 두 과제 간 목 표자극이 겹치지 않도록 하였다. 글자 대신 숫자로 자극을 선택한 이유는 대상자가 6세이기 때문에 글자로 된 자극을 빨리 인지하는 데에 어려움이 있을 수 있고, 주어진 시간 내에 가능한 빨리 과제의 해당 버튼을 누르는 데에 글자보다 숫자가 용이하다고 판단하였기 때문이다. 


\section{실험과제 제작}

실험과제는 E-Prime 소프트웨어를 사용하여 제작하였다. 시각 적 지속주의과제는 노트북 화면에 1 부터 5 까지 숫자가 무작위로 한 개씩 제시되고, 목표자극인 숫자 2 와 5 가 나올 때마다 해당 버 튼(space bar)을 누르는 과제이다. 자극 제시시간은 $500 \mathrm{~ms}$, inter stimulus interval (ISI)은 $1,000 \mathrm{~ms}$ 로, 결과적으로 1.5 초에 자극이 1 개씩 제시된다. 5 분의 전체 소요시간 동안 총 200 개 숫자가 제시되 고, 이때 목표자극인 2 와 5 는 80 회, 비목표자극인 1,3 과 4 는 120 회 제시된다. 청각적 지속주의과제는 노트북 스피커에서 1 부터 5 까지 의 숫자가 무작위로 1 개씩 제시되고, 목표자극인 숫자 1 과 4 가 들 릴 때 마다 해당 버튼(space bar)을 눌러야 한다. 시간 조건은 시각 적 지속주의과제와 동일하다. 청각적 지속주의과제의 경우 전체 5 분 동안 목표자극인 1 과 4 는 80 회, 비목표자극인 2,3 과 5 는 120 회 제시된다. Figures 1 과 2 는 시각적 지속주의과제와 청각적 지속주 의과제의 구성 예이다.

\section{연구절차}

예비 실험

본 실험에 앞서 과제의 수정 및 보완과 연구절차를 확정하기 위 해, 6 세 일반아동 3 명에게 예비 실험을 실시하였다. 실험 동안 2 명 의 아동이 어느 버튼을 눌러야 할지 몰라 계속 반응을 놓치거나, 과
제 방법을 충분히 숙지하지 못한 것이 관찰되었다. 이와 같은 문제 를 해결하기 위해 space bar에 빨간색 스티커를 붙여 버튼을 시각적 으로 더욱 두드러지게 하였고, 연습문항을 늘려 아동이 충분히 과 제 방법을 숙지할 수 있도록 하였다.

\section{본 실험}

소음이 적은 조용하고 독립된 공간에서 연구자는 아동과 일대일 상황에서 노트북을 사용하여 개별적으로 실험을 진행하였다. TD, pure SSD, SSD+LD의 세 집단을 다시 두 집단씩으로 나눠 한 집단 은 시각적 지속주의과제를, 나머지 한 집단은 청각적 지속주의과제 를 먼저 실시하여, 과제 순서에 따른 영향을 통제하였다. 시각적 지 속주의과제에서 숫자는 화면 정중앙에 제시되었고, 청각적 지속주 의과제에서 숫자의 소리크기는 노트북 audio output 세팅을 40 으 로 고정하여 동일하게 유지되었다. 시각적 지속주의과제의 경우, 아동에게 "지금부터 화면에 숫자가 나타날 거예요. 숫자 2, 숫자 5 가 나오면 바로 빨간색 버튼을 누르면 돼요. 다른 숫자가 나타나면 누르면 안 돼요.”라고 말한 다음 연습과제를 통해 수행방법을 숙지 시켰다. 과제 제시 전 아동으로 하여금 노트북 모니터에 집중하도 록 하였다. 청각적 지속주의과제는 아동에게 "지금부터 스피커에 서 숫자가 들릴 거예요. 숫자 1 , 숫자 4 가 들리면 바로 빨간색 버튼 을 누르면 돼요. 다른 숫자가 나타나면 누르면 안 돼요.”라고 말하
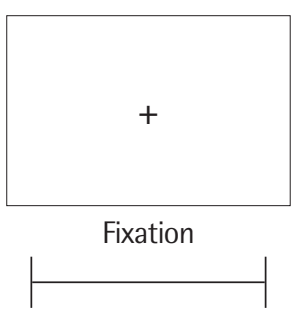

$500 \mathrm{~ms}$
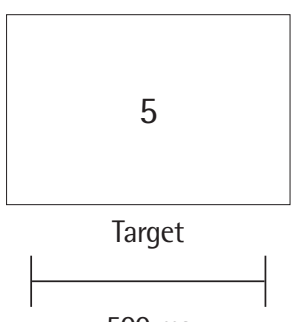

$500 \mathrm{~ms}$

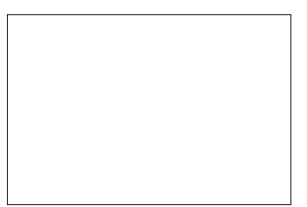

ISI

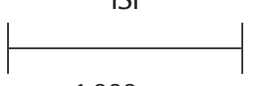

$1,000 \mathrm{~ms}$
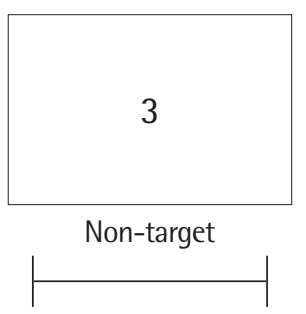

$500 \mathrm{~ms}$

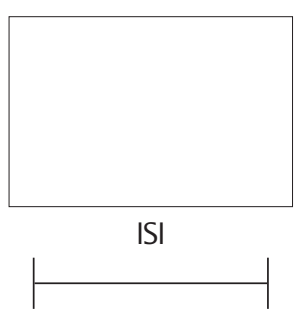

$1,000 \mathrm{~ms}$

Figure 1. The task of visual sustained attention. $|S|=$ inter stimulus interval.

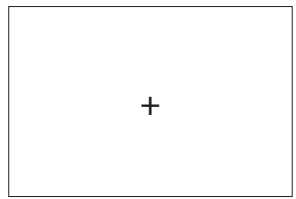

Fixation

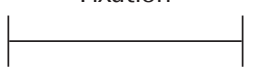

$500 \mathrm{~ms}$

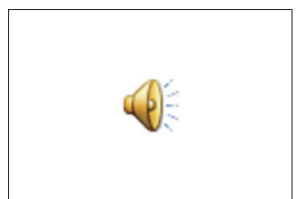

Target

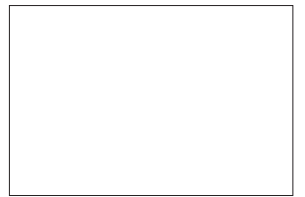

ISI

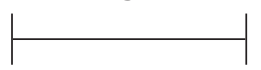

$1,000 \mathrm{~ms}$

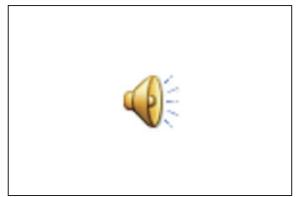

Non-target

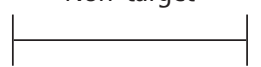

$500 \mathrm{~ms}$

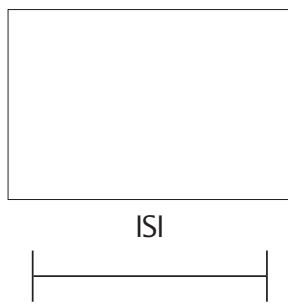

$1,000 \mathrm{~ms}$

Figure 2. The task of auditory sustained attention. $|S|=$ inter stimulus interval. 
였다. 마찬가지로 연습과제를 통해 수행방법을 숙지시켰고, 과제 제 시 전 아동을 노트북 스피커에 집중시켰다. 첫 번째 과제 실시 후 10 분의 휴지시간을 제공하여 목표자극 숫자의 학습효과를 통제 하 였다. 10 분의 휴지시간 동안에는 아동의 요구에 따라 간단한 이야 기 또는 놀이 활동을 하였다.

\section{자료 및 통계 분석}

정반응은 1 점, 오반응은 0 점으로 처리하여, 전체 정반응수를 각 과제의 정반응 점수로 하였다. 반응시간은 화면 또는 스피커에서 목 표자극이 제시된 순간부터 대상자가 해당 버튼을 누른 순간까지의 시간이다. 반응시간은 정반응한 항목에 대해서만 측정하였다. 각 과 제의 반응시간은 정반응한 모든 항목에 대한 평균 반응시간을 의미 한다. 상관관계 분석을 위해 수용어휘량과 표현어휘량은 수용·표현 어휘력검사의 수용어휘 원점수와 표현어휘 원점수를, 자음정확도 는 우리말 조음·음운평가의 자음정확도 수치를 각각 이용하였다.

자료의 통계처리는 SPSS version 23.0 (IBM, Armonk, NY, USA) 을 이용하여 분석하였다. 세 집단과 지속주의과제 유형 간 정반응 점수 및 반응시간에 차이가 있는지 알아보기 위해, 1 피험자 간-1피 험자 내 혼합설계에 따른 반복측정분산분석(repeated ANOVA)을 각각 실시하였다. 시각적 및 청각적 지속주의과제 점수와 반응시 간, 그리고 수용어휘, 표현어휘, 자음정확도 간 상관관계가 있는지 알아보기 위해 Pearson 적률상관관계 분석을 실시하였다. 세 집단 각각에서 상관관계를 분석할 경우 pure SSD와 SSD+LD 집단은 대 상자수가 10명씩으로 그 수가 너무 적어, 상관관계 분석은 pure $\mathrm{SSD}$ 와 $\mathrm{SSD}+\mathrm{LD}$ 를 합한 SSD 집단(20명)과 TD 집단(20명)의 두 집 단에서 실시하였다.

\section{연구결과}

\section{세 집단 간 자극 양식에 따른 지속주의과제의 정반응 점수 비교}

$\mathrm{TD}$, pure SSD 및 SSD+LD 집단에서 나타난 시각적 및 청각적 지 속주의과제의 정반응 점수에 대한 기술통계는 Table 2 와 같다. 시

Table 2. Descriptive analysis on the scores of visual and auditory sustained attention tasks by three groups

\begin{tabular}{lcc}
\hline & Visual sustained attention & Auditory sustained attention \\
\hline TD $(N=20)$ & $188.30(4.00)$ & $187.95(6.41)$ \\
Pure SSD $(\mathrm{N}=10)$ & $174.80(11.01)$ & $179.00(8.29)$ \\
SSD+LD $(\mathrm{N}=10)$ & $167.10(15.58)$ & $170.00(14.66)$ \\
\hline
\end{tabular}

Values are presented as mean (SD).

$\mathrm{TD}$ = typically developing; $S S D=$ speech sound disorder; $\mathrm{LD}=$ language disorder.
각적 과제와 청각적 과제 모두에서 $\mathrm{TD}$, pure $\mathrm{SSD}, \mathrm{SSD}+\mathrm{LD}$ 집단 순 으로 정반응 점수가 높은 것을 알 수 있다. 이와 같은 차이가 통계적 으로 유의한지 알아보기 위해 반복측정분산분석을 실시한 결과, 집단 간 차이가 유의하였다 $\left(F_{(2,37)}=18.600, p<.001\right)$. 그러나 집단 내 과제에 따른 차이 $\left(F_{(1,37)}=2.244, p>.05\right)$ 와 집단과 과제 간 상호 작용 효과 $\left(F_{(2,37)}=.988, p>.05\right)$ 는 유의하지 않았다. 집단 간 유의한 차이에 대해 Scheffé 사후검정을 실시한 결과, pure SSD 집단은 TD 집단보다 $(p<.01), \mathrm{SSD}+\mathrm{LD}$ 집단은 $\mathrm{TD}$ 집단 $(p<.01)$ 보다 점수가 유 의하게 떨어졌으나, pure SSD 집단과 $\mathrm{SSD}+\mathrm{LD}$ 집단 간 차이는 유의 하지 않았다 $(p>.01)$.

\section{세 집단 간 자극 양식에 따른 지속주의과제의 반응시간 비교}

$\mathrm{TD}$, pure $\mathrm{SSD}$ 및 $\mathrm{SSD}+\mathrm{LD}$ 집단에서 나타난 시각적 및 청각적 지 속주의과제의 반응시간에 대한 기술통계는 Table 3 과 같다. 시각적 과제와 청각적 과제 모두에서 $\mathrm{TD}$, pure $\mathrm{SSD}, \mathrm{SSD}+\mathrm{LD}$ 집단 순으로 평균적으로 반응시간이 빠른 것을 알 수 있다. 이와 같은 차이가 통 계적으로 유의한지 알아보기 위해 반복측정분산분석을 실시한 결 과, 집단 간 차이 $\left(F_{(2,37)}=4.699, p<.05\right)$ 가 유의하였다. 또한 과제에 따른 차이 $\left(F_{(1,37)}=34.208, p<.001\right)$ 가 유의하여, 청각 지속주의과제 보다 시각 지속주의과제에서 반응시간이 유의하게 빠르다는 것을 알 수 있었다. 그러나 집단과 과제 간 상호작용효과 $\left(F_{(2,37)}=.188\right.$, $p>.05)$ 는 유의하지 않았다. 집단 간 유의한 차이에 대해 Scheffé 사 후검정을 실시한 결과, $\mathrm{SSD}+\mathrm{LD}$ 집단은 $\mathrm{TD}$ 집단보다 반응시간이 유의하게 느렸으나 $(p<.01), \mathrm{SSD}$ 와 $\mathrm{TD}, \mathrm{SSD}$ 와 $\mathrm{SSD}+\mathrm{LD}$ 집단 간 차 이는 유의하지 않았다( $p>.05)$.

\section{시각적 및 청각적 지속주의과제 수행력과 수용어휘량, 표현어휘량, 자음정확도 간 상관관계}

$\mathrm{TD}$ 집단에서 수용어휘량, 표헌어휘량 및 자음정확도와 시각적 지속주의과제 정반응 점수의 상관계수는 .094, $.352, .068$ 이었고, 반응시간의 상관계수는 -.043, -.143, -.156이었다. 모두 통계적으로 유의하지 않았다 $(p>.05)$. 청각적 지속주의과제의 경우 TD 집단의

Table 3. Descriptive analysis on the reaction time (second) of visual and auditory sustained attention tasks by three groups

\begin{tabular}{lcc}
\hline & Visual sustained attention & Auditory sustained attention \\
\hline TD $(N=20)$ & $290.25(81.74)$ & $446.75(95.64)$ \\
Pure SSD $(\mathrm{N}=10)$ & $377.00(121.11)$ & $506.70(136.61)$ \\
SSD+LD $(\mathrm{N}=10)$ & $384.10(68.48)$ & $512.40(145.98)$ \\
\hline
\end{tabular}

Values are presented as mean (SD).

$\mathrm{TD}=$ typically developing; $\mathrm{SSD}=$ speech sound disorder; $\mathrm{LD}=$ language disorder. 
수용어휘량, 표헌어휘량 및 자음정확도와 정반응 점수의 상관계수 는 - $.265,-217, .051$ 이었고, 반응시간의 상관계수는 -.011, -.043, -.122 이었다. 마찬가지로 모두 통계적으로 유의하지 않았다( $p>.05)$.

전체 SSD 집단에서 수용어휘량, 표현어휘량 및 자음정확도와 시 각적 지속주의과제 정반응 점수의 상관계수는 $.287, .397, .677$ 이었 고, 반응시간의 상관계수는 $.139,-.078,-.430$ 이었다. 자음정확도와 시각적 지속주의과제의 정반응 점수 간 상관관계가 통계적으로 유 의하였고 $(p<.01)$, 나머지에서는 통계적 유의성이 관찰되지 않았다 ( $p>$.05). 청각적 지속주의과제의 경우 SSD 집단의 수용어휘량, 표 현어휘량 및 자음정확도와 정반응 점수의 상관계수는 .379, .459, .555 이었고, 반응시간의 상관계수는 $.152, .111, .142$ 이었다. 표현어휘 량 및 자음정확도와 청각적 지속주의과제의 정반응 점수 간 상관 관계가 통계적으로 유의하였고 $(p<.05)$, 나머지에서는 통계적 유의 성이 관찰되지 않았다 $(p>.05)$. 즉, 자음정확도와 시각적 지속주의 과제 정반응 점수 간, 표현어휘량 및 자음정확도와 청각적 지속주 의과제의 정반응 점수 간 유의한 상관관계가 있음을 알 수 있다.

\section{논의 및 결론}

본 연구결과 시각과 청각양식 모두에서 pure SSD 집단과 $\mathrm{SSD}+\mathrm{LD}$ 집단은 $\mathrm{TD}$ 집단보다 지속주의과제 정반응 점수가 유의하게 낮았 고, $\mathrm{SSD}+\mathrm{LD}$ 집단의 경우 두 자극 양식 모두에서 $\mathrm{TD}$ 집단보다 반 응시간도 유의하게 느렸다. 자극 양식에 따른 차이로는, 집단에 상 관없이 시각 지속주의과제의 반응시간이 청각 지속주의과제보다 유의하게 빠른 것으로 나타났다. TD 집단은 지속주의과제 수행력 과 대상자들의 수용어휘량, 표현어휘량, 자음정확도와 상관관계가 유의하지 않았던 반면, SSD 집단의 경우 청각 지속주의과제 정반 응 점수는 표현어휘량과 자음정확도와, 시각 지속주의과제 정반응 점수는 자음정확도와 유의한 정적 상관관계를 보였다.

임상적으로 주의력결핍장애로 진단받지는 않았지만, SSD 아동 은 언어장애 동반 여부에 상관없이 또래 일반 아동보다 주의력이 취약하다는 것을 알 수 있었다. 이러한 결과는 SSD 아동의 주의력, 특히 지속주의력 저하에 대해 보고한 선행연구(Murphy et al., 2014) 와 일치하는 결과이다. 더 나아가 본 연구에서는 반응시간에서 $\mathrm{SSD}+\mathrm{LD}$ 집단의 유의한 차이를 확인하여, $\mathrm{SSD}$ 아동이 언어장애를 동반한 경우 정반응을 할 때에도 또래 아동보다 더 오랜 시간이 필 요하다는 것도 확인하였다. 이러한 결과는 언어문제와 말소리문제 를 모두 보이는 경우 $\mathrm{ADHD}$ 동반 비율이 높다는 선행연구(McGrath et al., 2008)와 맥락을 같이 하는 것으로 보인다. 말소리 습득 과 언어 습득 모두 기본적으로 정상적인 주의력을 바탕으로 하기
때문에, 두 영역에서 결함을 같이 보이는 아동은 한 영역에서만 결 함을 보이는 아동보다 주의력이 보다 취약할 것으로 연구자들 또한 예측하였다. 반응시간 측면에서 연구자들의 예측을 확인할 수 있 었으며, 이는 정오반응뿐 아니라 반응시간 분석도 의사소통장애 아동의 특정 능력을 파악하는 데에 유용한 지표로 활용될 수 있음 을 시사한다.

집단 간 차이보다 더욱 흥미로웠던 결과는 자극 양식에 따른 것 이다. pure $\mathrm{SSD}$ 와 $\mathrm{SSD}+\mathrm{LD}$ 집단의 낮은 정반응 점수는 시각과 청 각 두 자극 양식 모두에서 확인되었고, $\mathrm{SSD}+\mathrm{LD}$ 집단의 느린 반응 시간은 두 자극 양식 모두에 해당하였다. 이러한 결과는 의사소통 장애 아동의 경우 청각적 지속주의 능력은 떨어지지만 시각적 지 속주의 능력은 보존하고 있다는 선행연구(Noterdaeme et al., 2001; Spaulding et al., 2008)와 상반된 것이다. 이는 본 연구자들의 예측 과도 어긋난 결과로, 연구자들은 말소리 측면에 결함이 있는 대상 자들이었던 만큼 말소리를 이용한 청각 과제에서 수행력이 유의하 게 더욱 떨어질 것으로 예상하였다. 더구나 SSD 집단은 청지각적으 로 민감성이 떨어지는 대상자를 포함하고 있을 수 있어, 그런 대상 자의 경우 주의력의 문제가 아니라 빠른 시간 안에 소리자극들을 변별해야 하는 청지각처리의 부담감 때문에라도 청각 과제에서 더 욱 어려움을 느낄 것이라 생각하였다. 이러한 결과에 대해서는 다 음과 같은 세 가지 가정을 해볼 수 있다.

Baddeley (2003)는 그의 작업기억 모델에서 입력되는 모든 정보 는 되뇌기에 의해 활성화되지 않으면 몇 초 안에 소멸되는 것으로 설명하면서, 되뇌기 기능을 하는 음운루프의 중요성을 강조하였다. 이 때 사람들은 시각적으로 정보가 제시되더라도 그것에 대응하는 소리 정보로 바뀌 되뇌기 활동을 하기 때문에, 시각 자극의 정보처 리도 음운처리 능력에 영향을 받는다고 덧붙였다. 이러한 Baddeley 의 이론에 근거할 때, 본 연구의 시각 지속주의과제에서 대상자들 은 시각적으로 제시되는 숫자 자극들을 소리 정보로 바꾸어 과제 를 수행하였을 가능성을 첫 번째로 가정해볼 수 있다. 그럴 경우 $\mathrm{SSD}$ 아동의 취약한 음운처리 능력은 시각적 과제 수행에도 부정적 인 영향을 주었을 것이다. 따라서 SSD 집단이 청각 지속주의과제 만큼 시각 지속주의과제에서도 그 수행력이 떨어졌다는 본 연구결 과는 SSD 집단의 낮은 음운처리 능력을 간접적으로 반영하는 것일 수 있다. 그러나 본 연구의 두 번째 연구질문인 반응시간에 대한 결 과를 고려하면, 이러한 가정이 타당성을 얻기에는 다소 부족함이 있다. 집단에 상관없이 시각 지속주의과제는 청각 지속주의과제보 다 반응시간이 빠르다는 것을 연구결과에서 확인하였다. 만일 대 상자들이 시각자극을 즉각적으로 처리하지 못하고 소리정보로 전 환하여 처리하였다면 시각자극 처리가 청각자극 처리보다 유의하 
게 빠르지 않았을 것이다. 때문에 Baddeley (2003)의 이론을 본 연 구에 적용하기 위해서는 본 연구결과만으로는 제한점이 있다고 여 겨진다.

주의력이 청각과 시각 양식에 대해 분리된 용량을 가지고 있는 지, 아니면 양식에 상관없이 하나의 공통된 자원으로 이루어져 있 는지에 대해 논란이 있다는 것은 서론에서 밝힌 바 있다. 두 번째 가 정은 이와 관련한 것으로, 음운처리 능력이 떨어지는 SSD 집단에 서 청각뿐 아니라 시각 과제에서도 수행력이 떨어졌다는 본 연구결 과는 주의력에 대한 후자의 가정을 보다 지지하는 것으로 보인다. 다시 말해 주의력은 모든 양식에 대해 단일 자원을 공유하기 때문 에, 주의력 결함이 있는 경우 시각이든 청각이든 자극 양식에 상관 없이 모든 주의 과제의 수행력은 떨어질 수밖에 없다고 가정해볼 수 있다. 그러나 이러한 가정과 더불어 SSD 아동이라고 하여 시각 처리 능력이 반드시 보존되어 있을 것으로 단정할 수 없기 때문에, 주의 체계가 양식에 따라 분리된 자원으로 이루어져 있지만 SSD 아동이 청각뿐 아니라 시각에서도 안정적이지 않은 주의력을 가지 고 있어 이와 같은 결과가 초래되었을 가능성도 배제할 수 없다. 따 라서 두 번째 가정이 보다 설득력을 얻기 위해서는 이에 대한 구체 적이고 심층적인 연구가 추후 이루어져야 할 것이다.

Shriberg 등(2005)은 잠재적인 원인에 의해 SSD 아동들을 7가지 하위유형으로 분류하였다. 이 가운데 5 번째 하위유형으로 발달기 심리사회적 문제를 동반한 SSD (developmental psychosocial involvement, SD-DPI) 그룹을 제안하였고, 이 후 SD-DPI를 또 다시 여러 하위그룹들로 나누어 다양한 특성들을 보고하였다. 이 가운 데 ‘충동적', '과격함', '공격적' 등의 문제와 더불어, '주의력 결핍', '인내심 부족', '어려운 과제에 대한 동기 결여'와 같은 증상을 SDDPI의 특성으로 거론하였다(Hauner, Shriberg, Kwiatkowski, \& Allen, 2005). 이와 같은 Shriberg 등(2005)의 연구에 근거하여 세 번째 가정을 해보면, 기질적으로 충동적이고 억제력이 부족한 아 동이 본 연구의 SSD 집단에 포함되었을 경우, SSD 아동의 지속주 의과제 수행력은 특정 양식에서만 선택적으로 결함을 보이기 보다 는 모든 자극 양식에서 집단적으로 떨어질 수밖에 없었을 것이다. 본 실험과제는 단순한 작업을 반복하는 과제이기도 하지만, 빠르 게 지나가는 자극에 집중하여 반응해야 하는 쉽지 않은 과제이기 도 하기 때문에, 어려운 과제에 대한 동기 결여 등의 특성도 수행력 저하에 영향을 미쳤을 것으로 보인다. 이러한 점들을 모두 고려할 때 본 연구결과에 대한 해석으로 세 번째 가정이 가장 설득력이 있 는 것으로 보인다. 그러나 SSD 집단은 매우 이질적인 집단이기 때 문에, 모든 SSD 아동들이 이런 기질적 특성을 가지고 있는 것은 아 니다. 따라서 추후 대상수를 많이 한 대규모 집단 연구를 통하여
$\mathrm{SSD}$ 하위그룹 간 수행력을 비교해보는 연구가 필요할 것이다.

집단 및 자극 양식에 따른 차이와 더불어, 본 연구에서는 SSD 집 단에서 청각 지속주의력이 표현어휘량 및 자음정확도와, 시각 지 속주의력 자음정확도와 유의한 정적 상관관계가 있음을 확인하였 다. TD 집단의 경우 자음정확도는 천장효과(ceiling effect)가 있었 고 수용어휘 및 표현어휘는 그 편차가 상대적으로 적었다는 점을 감안할 때(Table 1), TD 집단에서 유의한 상관관계가 나타나지 않 은 것은 당연한 결과로 판단된다. 따라서 $\mathrm{TD}$ 아동을 대상으로 할 때에는 보다 난이도가 있는 검사를 이용하여 실험과제와의 관련성 을 비교하여야 할 것이다. SSD 집단의 경우 구어산출(표현어휘량) 및 조음산출(자음정확도), 즉 산출 영역과 주의력에 유의한 정적 상관관계가 있었지만, 수용 영역(수용어휘량)과는 상관이 없었다. 주의력은 주로 외부 자극과 관련하여 다뤄지기 때문에 입력, 지각, 이해 측면과 주의력과의 관련성을 살펴본 연구들이 주로 이루어져 왔다. 물론 단어 또는 조음 산출의 문제는 습득 당시의 불완전한 입 력을 전제하고, 불완전한 입력은 주의력 저하와 관련이 있을 가능 성도 배제할 수 없다. 그러나 구어 및 조음 산출과 주의력이 유의한 관련성이 있다는 본 연구결과는 언어 산출 또는 표현 영역과 주의 력과의 관계에 대해 앞으로 보다 활발한 연구가 이루어져야 할 것 임을 시사한다.

이상과 같은 연구결과는 SSD 아동의 중재 시 주의해야 할 점에 대해서도 시사하는 바가 있다. SSD 아동은 방해자극에 쉽게 영향 을 받기 때문에 치료환경과 자극은 산만하지 않고 단순해야 할 것 이다. 특히 치료 초기에는 목표자극에 대한 집중력이 떨어지지 않 도록 목표자극만을 최대한 강조하고 외부적인 자극은 통제하는 것 이 필요할 것이다. 본 연구결과가 SSD 아동의 특성을 파악하고, 평 가 및 중재활동을 계획하는 데에 의미 있는 정보를 제공할 것으로 기대한다.

\section{REFERENCES}

Baddeley, A. (2003). Working memory and language: an overview. Journal of Communication Disorders, 36, 189-208.

Bird, J., \& Bishop, D. (1992). Perception and awareness of phonemes in phonologically impaired children. International Journal of Language \& Communication Disorders, 27, 289-311.

Broadbent, D. E. (1958). Perception and communication. New York, NY: Pergamon Press.

Brookshire, R. H. (2007). Introduction to neurogenic communication disorders (7th ed.). St Louis, MO: Mosby. 
Campbell, T. F., \& McNeil, M. R. (1985). Effects of presentation rate and divided attention on auditory comprehension in children with an acquired language disorder. Journal of Speech, Language, and Hearing Research, 28, 513-520.

Ellis Weismer, S. (1996). Capacity limitations in working memory: the impact on lexical and morphological learning by children with language impairment. Topics in Language Disorders, 17, 33-44.

Finneran, D. A., Francis, A. L., \& Leonard, L. B. (2009). Sustained attention in children with specific language impairment (SLI). Journal of Speech, Language, and Hearing Research, 52, 915-929.

Hanson, R. A., \& Montgomery, J. W. (2002). Effects of general processing capacity and sustained selective attention on temporal processing performance of children with specific language impairment. Applied Psycholinguistics, 23, 75-93.

Hauner, K. K., Shriberg, L. D., Kwiatkowski, J., \& Allen, C. T. (2005). A subtype of speech delay associated with developmental psychosocial involvement. Journal of Speech, Language, and Hearing Research, 48, 635-650.

Kenney, M. K., Barac-Cikoja, D., Finnegan, K., Jeffries, N., \& Ludlow, C. L. (2006). Speech perception and short-term memory deficits in persistent developmental speech disorder. Brain and Language, 96, 178-190.

Kim, Y. T., \& Shin, M. J. (2004). Urimal Test of Articulation and Phonology (U-TAP). Seoul: Hakjisa

Kim, Y. T., Hong, G. H., Kim, K. H., Jang, H. S., \& Lee, J. Y. (2009). Receptive \& expressive vocabulary test (REVT). Seoul: Seoul Community Rehabilitation Center.

Leitao, S., \& Fletcher, J. (2004). Literacy outcomes for students with speech impairment: long-term follow-up. International Journal of Language \& Communication Disorders, 39, 245-256.

Leonard, L. B. (1998). Children with specific language impairment. Cambridge, MA: MIT Press.
McGrath, L. M., Hutaff-Lee, C., Scott, A., Boada, R., Shriberg, L. D., \& Pennington, B. F. (2008). Children with comorbid speech sound disorder and specific language impairment are at increased risk for attention-deficit/hyperactivity disorder. Journal of Abnormal Child Psychology, 36, 151-163.

Murphy, C. F., Pagan-Neves, L. O., Wertzner, H. F., \& Schochat, E. (2014). Auditory and visual sustained attention in children with speech sound disorder. PloS One, 9, e93091.

Noterdaeme, M., Amorosa, H., Mildenberger, K., Sitter, S., \& Minow, F. (2001). Evaluation of attention problems in children with autism and children with a specific language disorder. European Child \& Adolescent Psychiatry, 10, 58-66.

Rucklidge, J. J., \& Tannock, R. (2002). Neuropsychological profiles of adolescents with ADHD: effects of reading difficulties and gender. Journal of Child Psychology and Psychiatry, 43, 988-1003.

Seo, E. Y., Ko, Y. K., Oh, G. A., \& Kim, S. J. (2017). Phonological awareness and vocabulary characteristics of children with speech sound disorders. Communication Sciences \& Disorders, 22, 318-327.

Shriberg, L. D., Lewis, B. A., Tomblin, J. B., McSweeny, J. L., Karlsson, H. B., \& Scheer, A. R. (2005). Toward diagnostic and phenotype markers for genetically transmitted speech delay. Journal of Speech, Language, and Hearing Research, 48, 834-852.

Sohlberg, M. M., \& Mateer, C. A. (2001). Cognitive rehabilitation: an integrative neuropsychological approach. New York, NY: Guilford Press.

Spaulding, T. J., Plante, E., \& Vance, R. (2008). Sustained selective attention skills of preschool children with specific language impairment: evidence for separate attentional capacities. Journal of Speech, Language, and Hearing Research, 51, 16-34.

Willcutt, E. G., \& Pennington, B. F. (2000). Comorbidity of reading disability and attention-deficit/hyperactivity disorder: differences by gender and subtype. Journal of Learning Disabilities, 33, 179-191. 


\section{국문초록}

\section{순수 말소리장애 아동과 언어장애 동반 말소리장애 아동의 시각 및 청각 지속주의 특성 \\ 주미진,2. 하지완 ${ }^{13}$ \\ ${ }^{1}$ 대구대학교 재활과학대학원 언어치료학과, ${ }^{2}$ 자모언어심리발달센터, ${ }^{3}$ 대구대학교 언어치료학과}

배경 및 목적: 본 연구에서는 순수 말소리장애 아동, 언어장애를 동반한 말소리장애 아동, 일반 아동을 대상으로 시각과 청각의 자극 양식에 따른 지속주의과제 수행력을 비교하고, 수용어휘량, 표현어휘량, 자음정확도와 지속주의 수행력과의 상관관계를 살펴보았다. 방법: 연구대상자는 6 세 말소리장애 아동 20 명(순수 말소리장애 10 명, 언어장애 동반 말소리장애 10 명)과 일반 아동 20 명이었다. EPrime 소프트웨어로 숫자자극을 이용하여 시각적 및 청각적 지속주의과제를 제작하였다. 대상자들에게 개별적으로 실험을 진행한 후, 지속주의 정반응 점수와 반응시간을 측정하였다. 결과: 순수 말소리장애 집단과 언어장애 동반 말소리장애 집단은 일반 집단에 비 해 지속주의과제의 정반응 점수가 유의하게 낮았다. 언어장애 동반 말소리장애 집단의 경우 반응시간도 일반 집단보다 유의하게 느렸 다. 자극 양식에 따른 정반응 점수의 차이는 유의하지 않았으나, 반응시간에서는 집단에 상관없이 시각 과제가 청각 과제보다 유의하게 빨랐다. 일반 집단에서는 지속주의 수행력과 수용어휘량, 표현어휘량, 자음정확도 간 유의한 상관관계가 관찰되지 않았으나, 말소리장 애 집단의 경우 자음정확도는 시각과 청각 지속주의과제의 정반응 점수와, 표현어휘량은 청각 지속주의과제의 정반응 점수와 유의하 게 상관이 있었다. 논의 및 결론: 본 연구결과는 말소리장애와 관련한 요인으로 지속주의 결함의 가능성을 시사하고 있으며, 말소리장 애아동의자음정확도 및 표현어휘 발달과주의력 간 관련성을 제시하고 있다.

핵심어: 순수 말소리장애, 언어장애 동반 말소리장애, 시각적 지속주의, 청각적 지속주의

본 연구는 2015학년도 대구대학교 학술연구비 지원에 의하여 연구되었음(No. 20150400).

\section{참고문헌}

김영태, 신문자(2004). 우리말 조음·음운평가(U-TAP). 서울: 학지사.

김영태, 홍경훈, 김경희, 장혜성, 이주연(2009). 수용·표현어휘력검사(REVT). 서울: 서울장애인종합복지관.

서은영, 고유경, 오경아, 김수진(2017). 말소리장애 아동의 음운인식과 어휘 특성. 언어청각장애연구, 22, 318-327. 